\title{
A new species of the catfish genus Cambeva from the Paranapanema river drainage, southeastern Brazil (Siluriformes: Trichomycteridae)
}

\author{
Axel M. Katz* and Wilson J.E.M. Costa \\ Laboratório de Sistemática e Evolução de Peixes Teleósteos, Departamento de Zoologia, \\ Universidade Federal do Rio de Janeiro, Cidade Universitária, Caixa Postal 68049, \\ CEP 21944-970, Rio de Janeiro, RJ, Brazil
}

Received for publication: 30 April 2019; Revision received: 30 September 2019; Accepted for publication: 5 March 2020

\begin{abstract}
The recently described catfish trichomycterid genus Cambeva comprises about 25 valid species, occurring mostly in river basins of south-eastern and southern Brazil. Fifteen species are endemic to the Paraná river basin, of which three are endemic to the Paranapanema river drainage. Herein we describe a fourth new species, Cambeva guareiensis n. sp., known only from the Guareí river. Cambeva guareiensis is similar to C. brachykechenos, C. cubataonis, C. diabola, C. davisi, C. diatropoporos, C. pascuali, C. poikilos and C. stawiarski by having a colour pattern consisting of dark brown spots scattered on the flank and can be differentiated by an exclusive combination of characters, including: the shape of the autopalatine; number of branchiostegal, anal-fin, dorsal-fin, dorsal and ventral caudal procurrent, and pectoral-fin rays; number of interopercular and opercular odontodes; number of vertebrae; and, insertion of anal fin, pelvic fin and urogenital papillae. This study indicates the potential for discovering a greater still unknown trichomycterid species diversity in the Paraná river basin.

http://zoobank.org/urn:lsid:zoobank.org:pub:7450C6D2-11BE-47EA-99AD-82C59DD $2117 C$
\end{abstract}

Key words: Taxonomy; Paraná River basin; biodiversity; Trichomycterinae; Neotropic.

\section{Introduction}

Popularly known as catfishes, the Siluriformes are among the most diverse vertebrate orders, with about 3700 species (Nelson et al. 2016; Fricke et al. 2019). Among Siluriformes, the Trichomycteridae is the second most diverse family, with over 300 valid species (Fricke et al. 2019). Trichomycterid catfishes are unique among other fish groups by all presenting a highly modified opercular bones and associated muscles, often used to climb waterfalls (Eigenmann 1918; Arratia 1983).

The Trichomycterinae is the most diverse subfamily of Trichomycteridae, occurring between Costa Rica in Central America and Patagonia in southern South America (Datovo

\footnotetext{
*Corresponding author. E-mail: axelmk@gmail.com

${ }^{\circ}$ Copyright: the Author(s), 2020 | Licensee PAGEPress, Italy
} 
and Bockmann 2010; Ochoa et al. 2017; Katz et al. 2018). Until recently Trichomycterinae and its genus Trichomycterus Valenciennes, 1832 were among the most controversial Neotropical fish groups, often considered paraphyletic (Baskin 1973, Arratia et al. 1978; de Pinna 1989; Arratia 1990; Costa and Bockmann 1993). However, recent morphological and molecular studies have consistently supported monophyly of the Trichomycterinae (Datovo and Bockmann 2010; Ochoa et al. 2017; Katz et al. 2018), as well as a more recent generic delimitation based on a multigene analysis proposed a new classification for part of the Trichomycterinae, where, Trichomcyterus was restricted to a clade containing the type species, T. nigricans Valenciennes, 1832 and several other species from eastern Brazil (Katz et al. 2018). In the last cited study, Trichomycterus was strongly supported as sister group to a clade containing Scleronema Eigenmann, 1917 and a clade then named as a new genus Cambeva Katz, Barbosa, Mattos \& Costa, 2018.

Species of Cambeva can be distinguished from all other trichomycterines by the presence of a bony flap on the maxillo-dentary ligament of the dentary channel and by having the interopercle shorter than the opercle, a deep constriction on the basal portion of the anterodorsal arm of the quadrate, absence of teeth in the coronoid process of the dentary, the maxilla shorter than the premaxilla, the cranial fontanel extending from the medial posterior portion of frontal to the medial region of the supraoccipital, and by the absence of the postorbital process of the sphenotic, prootic and pterosphenoid (Katz et al. 2018). Cambeva comprises about 25 valid species, occurring in river basins of south-eastern and southern Brazil (Katz et al. 2018), with each species usually found in isolated river headsprings with highly oxygenated waters, often exhibiting the habit of hiding in the bottom substrate (Bockmann et al. 2004; Katz and Barbosa 2014; Katz et al. 2018). Most species (15) of Cambeva are endemic to the Paraná river basin, of which three are endemic to the Paranapanema river drainage (Nascimento et al. 2017; Bockmann et al. 2004; Ochoa et al. 2017). In the present study, we describe a new species from the upper section of the Paranapanema river drainage.

The material is deposited in the collections of the Departamento de Zoologia of the Universidade Federal do Rio de Janeiro (UFRJ) and the Museu Nacional do Rio de Janeiro (MNRJ).

\section{Material and methods}

Measurements and counts follow Barbosa and Costa (2003). Measurements are presented as percentages of standard length (SL), except for subunits of head, which are presented as percentage of head length (HL). Counts of procurrent caudal-fin rays, vertebrae, branchiostegal rays, teeth and odontodes were made only in cleared and stained specimens (C\&S) prepared according to Taylor and Van Dyke (1985). Terminology for osteological nomenclature follows Datovo and Bockmann (2010). Nomenclature and homologies for supraorbital and infraorbital sensory canal systems follow Arratia and Huaquin (1995). Comparative material appears in supplementary material, available on line.

\section{Taxonomy}

\section{Cambeva guareiensis n. sp.}

(Figures 1-4)

urn:lsid:zoobank.org:act:EA9A6D10-F84D-4E22-9A11-15F66C4C3D3B

\section{Material examined}

Holotype. UFRJ 12173, 59.5 mm SL, Brazil: São Paulo State: Angatuba Municipality: 
Correntes waterfall, in Guareí river of the Paranapanema river drainage, Paraná river basin, $23^{\circ} 26^{\prime} 05^{\prime}$ 'S , 48 23'19' W, altitude about $650 \mathrm{~m}$ a.s.1., leg. P. Hamilton \& V.M. AzevedoSantos, 6.XI.2017.

Paratypes. 19 ex., UFRJ 12170, 14.3-52.1 mm SL; 6 ex. (C\&S), UFRJ 12171, 34.6$54.1 \mathrm{~mm}$ SL; 10 ex., MNRJ 51423, 25.1-37.3 mm SL, same locality as holotype, leg. H. Rodrigues \& V.M. Azevedo-Santos, 26.VII.2017; 3 ex., UFRJ 12172, 40.5-52.1 mm SL, collected with holotype.

\section{Diagnosis}

Cambeva guareiensis is distinguished from all other congeners except Cambeva brachykechenos (Ferrer \& Malabarba, 2013), C. cubataonis (Bizerril, 1994), C. diabola (Bockmann, Casatti \& de Pinna, 2004), C. davisi (Haseman, 1911), C. diatropoporos (Ferrer \& Malabarba, 2013), C. pascuali (Ochoa, Silva, Silva, Oliveira \& Datovo, 2017),

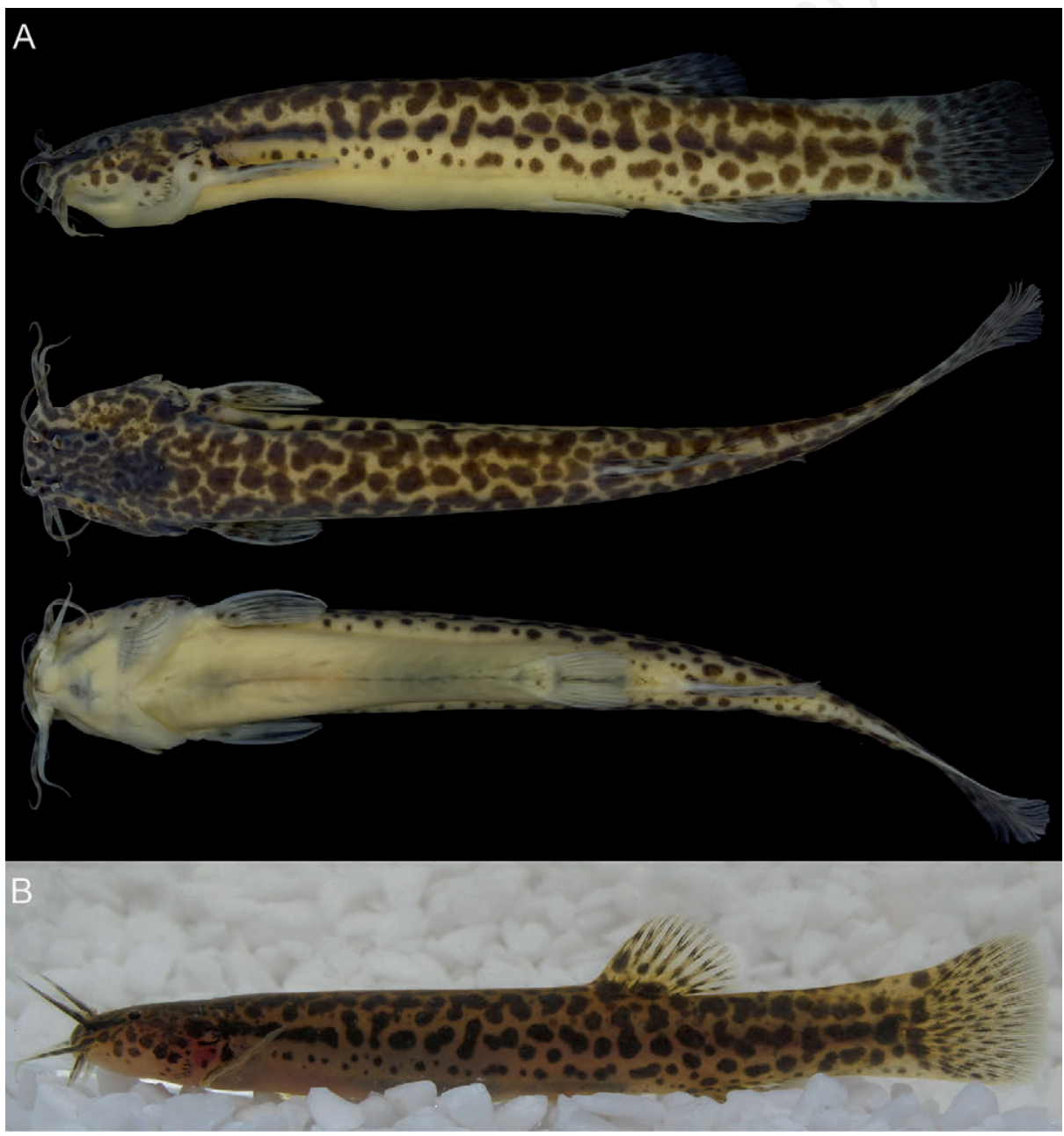

Figure 1. Cambeva guareiensis n. sp. A, UFRJ 12173 holotype, 51.2 mm SL; Brazil: São Paulo State State: Angatuba: Paranapanema river basin; B, live holotype. 
C. poikilos (Ferrer \& Malabarba, 2013), and C. stawiarski (Miranda Ribeiro, 1968) by having a colour pattern consisting of dark brown spots scattered on the flank (Figures 1, 3) ( $v s$. plain brown, often with minute brown dots, sometimes with stripes). Distinguished from $C$. brachykechenos, $C$. diabola, $C$. poikilos and $C$. stawiarski by having the mesial margin of autopalatine with deep concavity (vs. straight in C. poikilos and C. stawiarski or just slightly concave in $C$. brachykechenos and $C$. diabola); from $C$. brachykechenos, $C$. diabola, C. diatropoporos and C. stawiarski by the presence of 8-9 anal-fin rays (vs. 6-7 in C. brachykechenos and C. diatropoporos; and 10 in C. diabola and C. stawiarski); from C. brachykechenos, $C$. diabola, C. pascuali and C. poikilos by having 7 pectoral-fin rays (vs. 5 in C. pascuali; 6 in C. brachykechenos and C. poikilos; and 8 in C. diabola); from C. brachykechenos, C. diatropoporos, C. pascuali and C. stawiarski by having 35-36 vertebrae (vs. 37-41); from C. brachykechenos, C. diabola, and C. stawiarski by having the anal-fin insertion in the vertical through centrum of the $23 \mathrm{th}-24$ th vertebrae (vs. $21 \mathrm{st}-$ 22th in C. brachykechenos and C. stawiarski; and 25th-26th in C. diabola); from C. davisi, C. pascuali and C. stawiarski by having 8 branchiostegal rays (vs. 7 in C.pascuali and 911 in $C$. davisi and C. stawiarski); from C. cubataonis, C. diabola and C. poikilos by the presence of 11 dorsal-fin rays (vs. 7-9 in C. poikilos and 12 in C. cubataonis and $C$. diabola); from C. cubataonis, C. diabola and C. stawiarski by having the pelvic-fin origin in the vertical through centrum of the 17 th vertebrae (vs. 16th in C. cubataonis, 21 st in $C$. diabola and 16th in C. stawiarski), the dorsal-fin origin in the vertical through centrum of 19th-20th vertebrae (vs. 17th-18th in C. cubatoanis and C. stawiarski and 21st-22th in C. diabola), and the anal-fin origin in the vertical through the 9th or 10th dorsal-fin ray base (vs. anterior to the dorsal-fin base in C. diabola and C. stawiarski); from C. davisi and C. stawiarski by possessing the urogenital papillae in the vertical through centrum of the $21 \mathrm{st}-$ 22 th vertebrae (vs. 23th-24th in C. davisi and 20th in C. stawiarski); from C. cubataonis and C. stawiarski by the presence of 10-13 opercular odontodes (vs. 14-19); from $C$. stawiarski by the presence of 14-20 dorsal procurrent rays on the caudal fin (vs. 27), and 25-32 interopercular odontodes (vs. 40); and from C. pascuali by the presence of pelvic fin (vs. absence), 12-13 pleural ribs (vs. 14), 25-32 interopercular teeth (vs. 11-12), and 9-12 procurrent ventral rays on the caudal fin (vs. 15-16).

\section{Description}

Morphometric data for holotype and paratypes given in Table 1. Body subcylindrical on anterior portion, compressed on caudal peduncle. Dorsal profile slightly convex between snout and end of dorsal-fin base, straight on caudal peduncle. Ventral profile straight to slightly convex between lower jaw and end of anal-fin base, slightly concave on caudal peduncle. Greatest body depth in vertical immediately in front of pelvic-fin origin. Skin papillae minute. Urogenital papilla conical, in vertical through centrum of 21 st-22th vertebrae.

Head trapezoidal in dorsal view. Mouth subventral. Tip of nasal, maxillary and rictal barbels reaching anterior edge of interopercular patch of odontodes. Tip of maxillary barbel not reaching pectoral-fin base. Interopercular odontodes 25-32; opercular patch of odontodes broad, with 10-13 odontodes; odontodes conical (Figure 2A).

Anterior cornua of mesenthmoid straight. Anterior fontanel straight immediately anterior to epiphyseal bar. Posterior cranial fontanel long and broad between frontals and extending into parieto-supraoccipital. Sphenotic, prootic and pterosphenoid entirely fused to each other (Figure 2B). Vomer arrow-shaped with long posterior process. Antorbital about $1 / 3$ of supraorbital length. Sesamoid supraorbital rod-like. Autopalatine square-like, 
with anterior margin convex, mesial margin deeply concave, distal margin slightly concave and small posterior process extending slightly over metapterygoid (Figure 2C).

Premaxilla with 3 rows of conical teeth; anteriormost row with 12-14 teeth. Maxilla large, boomerang-shaped and more slender than premaxilla. Lower jaw with bone flap over maxilla-dentary channel, 3 rows of conical and spatulate teeth, most external row with 1419 teeth (Figure 2D).

Metapterygoid sub-triangular, wider than deep, without distinct processes. Dorsal surface of hyomandibula with deep concavity. Articulation between metapterygoid and quadrate restricted to cartilage block. Preopercle slender, sub-triangular, covering ventral margins of quadrate and hyomandibula (Figure 2A).

Hypohyal subtriangular in ventro-lateral view, with elliptical hollow; anterior ceratohyal long, posterior ceratohyal short, about one third anterior ceratohyal; branchiostegal rays 8; lateral process of parurohyal short and robust, extremity truncate, posterior process short and narrow, anterior process settled in elliptical hollow of hypohyal (Figure 2E).

Anterior tip of basibranchial axis extending to level of hypobranchials 1, not reaching dorsal surface of urohyal keel, with posterior tip situated immediately in front of anteromedial region of contralateral hypobranchials 3. Ossification of basibranchial 2 nearly as long as bony portions of basibranchial 3 and hypobranchial 1. Basibranchial 4 completely cartilaginous, represented by sub-rectangular plate. Basibranchial 4 bordered anteriorly by hypobranchials 3 , laterally by cartilaginous heads of ceratobranchials 4 , and posteriorly by cartilaginous heads of ceratobranchials 5. Hypobranchial 1 rod-like, with

Table 1. Morphometric data for holotype and paratypes of Cambeva guareiensis $(\mathrm{n}=16$ including the holotype).

\begin{tabular}{lcccc} 
& Holotype & $\mathbf{n = 1 6}$ & MEAN & SD \\
\hline Standard length $(\mathrm{mm})$ & 51.2 & $34.48-59.5$ & & \\
\hline $\begin{array}{l}\text { Percentage of Standard length } \\
\text { Body depth }\end{array}$ & 13.7 & $11.3-16.0$ & 13.6 & 1.3 \\
\hline Caudal peduncle depth & 11.3 & $7.9-12.6$ & 11.0 & 1.1 \\
\hline Body width & 7.5 & $7.2-12.4$ & 8.8 & 1.7 \\
\hline Caudal peduncle width & 3.5 & $3.3-5.4$ & 4.1 & 0.7 \\
\hline Dorsal-fin base length & 10.4 & $8.7-11.5$ & 10,3 & 0.8 \\
\hline Anal-fin base length & 8.0 & $6.9-10.4$ & 8.4 & 0.9 \\
\hline Pelvic-fin base length & 8.8 & $7.1-11.0$ & 8.6 & 1.0 \\
\hline Pectoral-fin length & 13.9 & $10.8-14.5$ & 13.0 & 1.0 \\
\hline Pre-dorsal length & 62.3 & $56.0-65.6$ & 61.2 & 2.7 \\
\hline Pre-pelvic length & 54.1 & $50.4-56.8$ & 54.0 & 1.7 \\
\hline Head length & 15.2 & $15.2-20.8$ & 17.6 & 1.8 \\
\hline
\end{tabular}

\section{Percentage of Head length}

\begin{tabular}{lcccc} 
Head depth & 65.9 & $48.0-65.9$ & 57.6 & 5.5 \\
\hline Head width & 103.8 & $82.9-106.2$ & 95.2 & 6.9 \\
\hline Interorbital distance & 37.8 & $29.6-37.9$ & 33.5 & 2.7 \\
\hline Snout length & 50.0 & $34.4-50.8$ & 44.7 & 4.4 \\
\hline Eye diameter & 12.8 & $7.5-13.0$ & 10.1 & 1.9
\end{tabular}

SD, Standard deviation. 

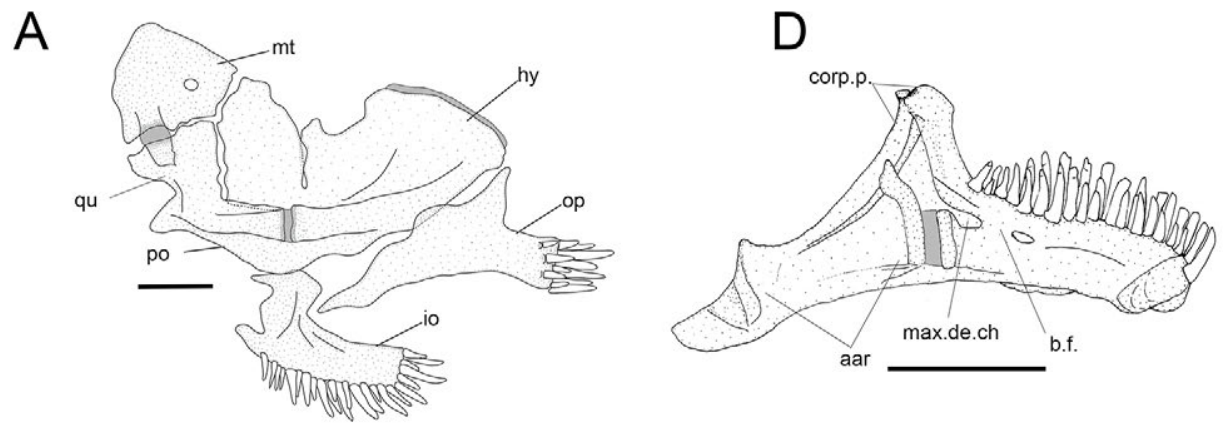

B
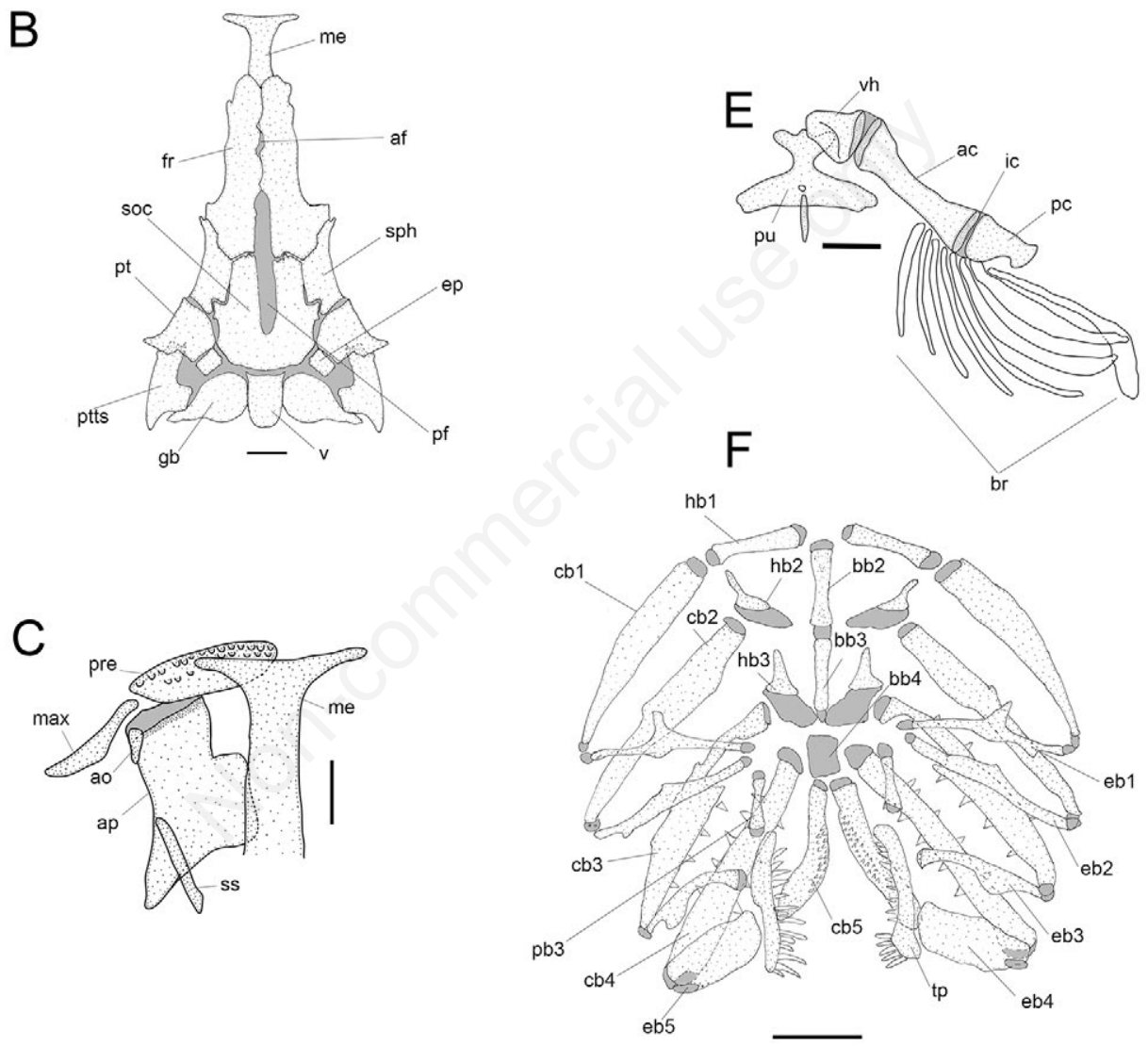

Figure 2. Cambeva guareiensis n. sp., UFRJ 12171, $49.2 \mathrm{~mm} \mathrm{SL}$. A, left suspensory in dorsal view; $\mathrm{B}$, cranium in dorsal view; $\mathrm{C}$, left autopalatine in dorsal view; $\mathrm{D}$, Left lower jaw in medial view; $\mathrm{E}$, left hyoid arch in dorsal view; F, branchial skeleton in dorsal view. Abbreviations: ac, anterior ceratohyal; af, anterior fontanel; ao, antorbital; ap, autopalatine; bb2-4, basibranchials 2 to 4; b.f. bone flap; br, branchiostegal rays; cb1-5, ceratobranchials 1 to 5; corp.p, coronoid process; de, dentary; eb1-5, epibranchials 1 to 5; ep, epioccipital; fr, frontal; gb, gasbladder capsule; hb1-3, hypobranchials 1 to 3; hy, hyomandibula; ic, inter-ceratohyal cartilage; io, interopercle; max.de.ch., maxillo-dentary channel; me, mesethmoid; mt, metapterygoid; mx, maxilla; op, opercle pb3-4; pharyngobranchials 3 and 4; pc, posterior ceratohyal; pf, posterior fontanel; pm, premaxilla; po, preopercle; ptts, posttemporo-supracleithrum; pt, pterotic; qu, quadrate; sph, sphenotic; ss, sesamoid supraorbital; soc, parieto-supraoccipital; tp, tooth plate; vh, ventral hypohyal. Scale bar $=1 \mathrm{~mm}$. 
cartilage only in its proximal and distal tips, and without uncinate process on its anterodistal portion. Hypobranchial 2 elongate, approximately triangular, mostly cartilaginous except for pointed, anterolaterally-oriented, process on its anterodistal region. Hypobranchial 3 approximately triangular, closely positioned relative to its counterpart, mostly cartilaginous except for pointed, antero-laterally-oriented, process on its anterodistal region. Ceratobranchials well-ossified, with small cartilage at their extremities. Proximal portion of ceratobranchial 3 with concavity at its posterior margin. Ceratobranchial 5 supporting patch of fine 12-16 conical teeth arranged in 2 rows, teeth of most mesial row distinctly larger. Epibranchials 1-3 rod-like and well-ossified, except at tips. Anterior margin of epibranchial 1 with prominent elongate uncinate process. Anterior border of epibranchial 2 with small blunt process. Posterior margin of epibranchial 3 with robust uncinate process. Epibranchial 4 broad, rectangular. Epibranchial 5 minute, oval, cartilaginous, situated close to distal cartilaginous head of ceratobranchial 4. Pharyngobranchials 1 and 2 absent. Pharyngobranchial 3 elongate, rod-like. Pharyngobranchial 4 well-ossified and elongate, ventrally attached to well-developed upper pharyngeal tooth plate, bearing 14-18 fine conical teeth arranged in 2 rows, with 4-5 most posterior teeth larger and curved at their tips (Figure 2E).

Dorsal and anal fins sub-triangular, with slightly convex distal margin. Origin of dorsal fin posterior to middle of total length, in vertical through centrum of 19th-20th vertebrae; anal-fin origin in vertical of 9th-10th dorsal-fin base rays, through centrum of 23th-24th vertebrae. Caudal fin truncate. Pectoral fin well-developed, sub-triangular, lateral and posterior edges slightly convex, fin insertion posterior to opercular membrane; tip of first pectoral-fin ray not prolonged as filament. Pelvic fin shorter than anal fin, covering urogenital opening, but tip not reaching anal fin, in vertical just anterior to dorsal-fin origin; pelvic-fin insertion through centrum of 17 th vertebra; pelvic girdle short with mesial process; pelvic-fin bases medially in close proximity. Dorsal-fin rays III+6-7; anal-fin rays II-III +6 ; caudal-fin principal rays I $+6+5+$ I, dorsal procurrent rays $14-20$, ventral procurrent rays $9-12$; pectoral-fin rays $\mathrm{I}+6$; pelvic-fin rays $\mathrm{I}+4$.

Upper hypural plates separated, ventral plate slightly wider than dorsal plate. Total vertebrae 35-36. Pleural ribs 12-13. First pleural rib straight and much thicker than second rib. First complete hemal spine on 18th-19th vertebrae.

Head sensory canals with simple (non-dendritic) tubes ending in single pores. Supraorbital sensory canal continuous and connected to optic and infraorbital sensory canals posteriorly. Supraorbital sensory canal bearing 3 branches and pores s1, s3, and s6 (epiphyseal branch and pore); s2, s4, s5, s7, and s8 (parietal) branches and pores absent. Otic sensory canal short, without pores, and continuous with posterior limits of supra- and infraorbital sensory canals, anteriorly, and with anterior limit of postotic sensory canal, posteriorly. Postotic (or temporal) sensory canal extends from posterior limit of otic sensory canals to anterior limit of lateral line, bearing 2 branches and pores (po1 and po2). Infraorbital sensory canal with one segment with 2 branches and pores (i10 and i11), i1 and 13 branches and pores absent. Preoperculomandibular sensory canal absent. Lateralline canal very short, with 2 pores, extending from posteriormost region of opercle to above middle of pectoral fin. Conspicuous rostral line of neuromasts surrounding anterior limit of anterior nostril.

\section{Colouration}

Flank yellow with dark rounded brown spots, larger and more concentrated on dorsal half of flank and whole peduncle caudal side, their diameter twice or more eye diameter, 
sometimes coalesced on lateral midline; spots on anteroventral portion of flank smaller, equal or slightly larger than eye diameter. Dorsal surface between head and dorsal fin yellow with dark brown blotches. Venter pale yellow. Head side light yellow with small dark brown spots. Interopercular and opercular patches of odontodes yellow, sometimes with minute dark brown dots. Distal part of barbels yellow, proximal part brown. Fins hyaline, with transverse rows of dark brown spots (Figures 1A,B; 3A,B).

\section{Distribution}

Cambeva guareiensis is only known from a small stream tributary to the Guareí River, tributary of upper section of the Paranapanema river drainage, Paraná river basin (Figure 4).

\section{Etymology}

The name guareiensis refers to the occurrence of the new species in the Guareí river drainage, a noun in apposition.

\section{Discussion}

Currently five species of Cambeva have been reported to occur in the Paranapanema river drainage: C. davisi, C. diabola, C. guareiensis, C. pascuali and C. perkos (Datovo, Carvalho \& Ferrer, 2012). Although phylogenetic relationships among species of Cambeva are still unknown and osteological data for most taxa are not available, C. guareiensis n. sp. seems to be more closely related to $C$. davisi and $C$. cubataonis by these three species sharing a unique morphology of autopalatine consisting of a deep constriction on the mesial margin of the autopalatine, with the anterior part of the margin nearly straight and the posterior prominent and rounded (Figure $2 \mathrm{C}$ ). In other taxa that constriction is absent. Cambeva guareiensis is readily distinguished from $C$. davisi by the relative position of the urogenital papillae that is situated in the vertical through the centrum of 21 st-22th vertebrae (vs. 23th-24th in C. davisi), and by the presence of eight branchiostegal rays (vs. nine to

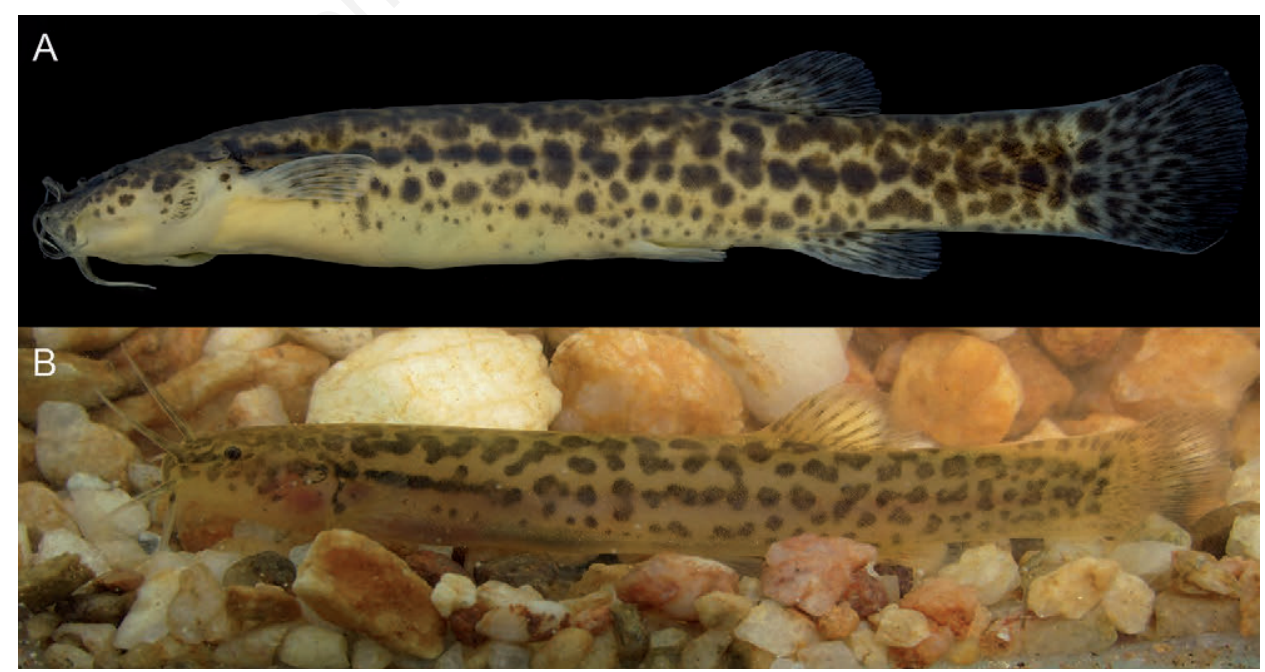

Figure 3. Cambeva guareiensis n. sp., Brazil, São Paulo State State, Angatuba, Paranapanema river basin. A, UFRJ 12172 paratype, $59.5 \mathrm{~mm} \mathrm{SL}$; B, UFRJ 12170 live paratype, $33.5 \mathrm{~mm}$ SL. 
eleven). In addition, these two species may be easily distinguished by their adult colour pattern, with $C$. guareiensis having round dark brown spots over flank highly contrasting with the yellow colour ground (Figures 1A,B; 3A,B), whereas in C. davisi there are minute brown spots highly overlapped over flank, weakly contrasting with the yellowish-brown colour ground (Figure 5A). The distribution of $C$. davisi is much wider than that of $C$.

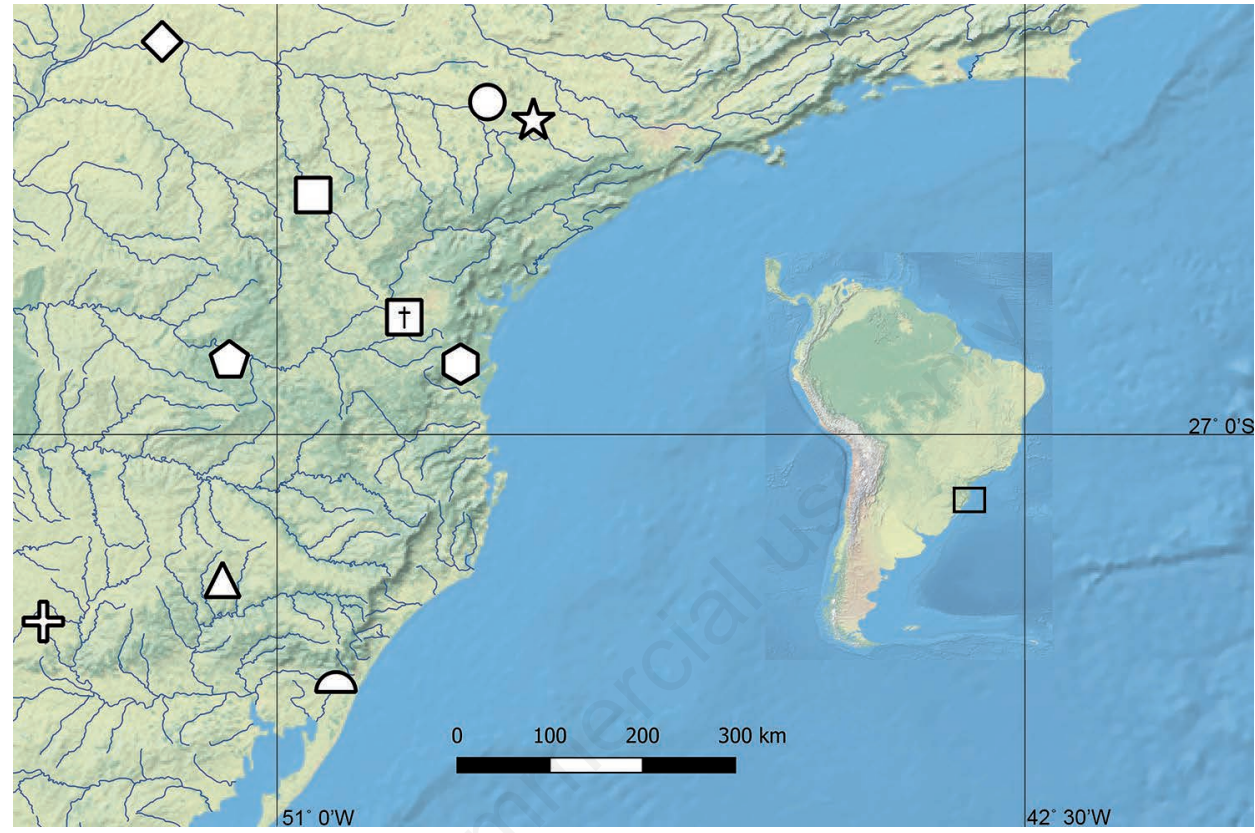

Figure 4. Distribution of Cambeva brachykechenos (half circle); C. cubataonis (hexagon); C. diabola (diamond); $C$. davisi (square with cross, type locality in the Iguaçu river dranage; square non type locality in the Paranapanema river drainage); C. diatropoporos (triangle); C. pascuali (circle); C. poikilos (cross); C. stawiarski (pentagon); and C. guareiensis (star).

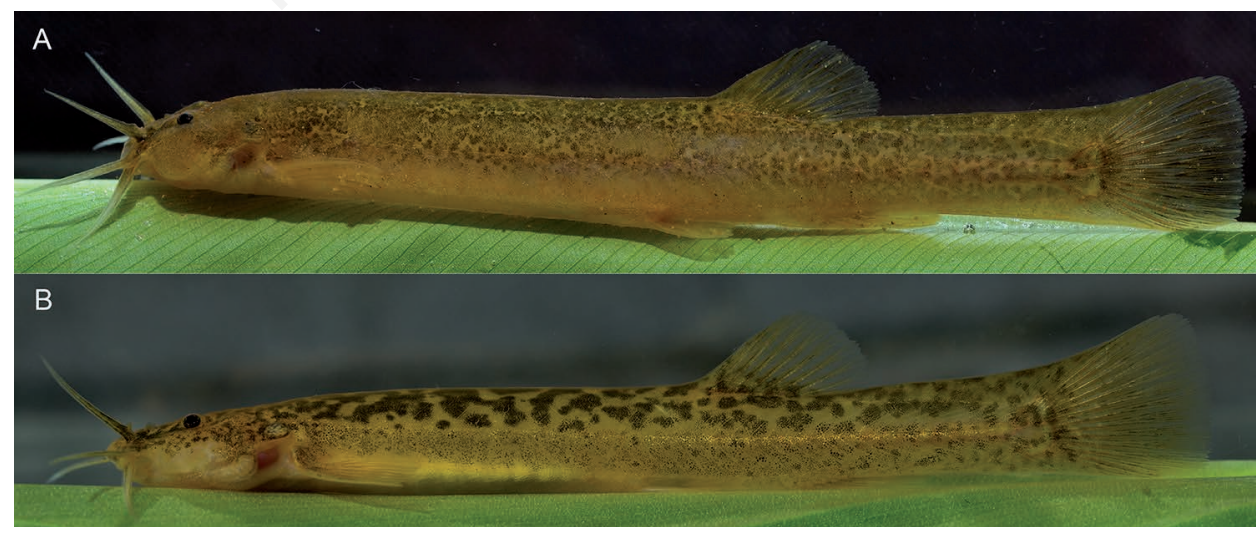

Figure 5. A, Cambeva davisi, topotype, UFRJ 9759, 67.6 mm SL, Brazil, Paraná, Balsa Nova; B, Cambeva cubataonis, UFRJ 10603, 51.6 mm SL, Brazil, Santa Catarina, Florianópolis. Photograph by A.M. Katz. 
guareiensis, occurring both in the Iguaçu and Paranapanema river drainages (Nascimento et al. 2017) (Figure 4). However, even with this wider distribution recorded for C. davisi, there is a considerable distance between the localities where the two species occur in the Paranapanema river drainage (Figure 4).

Cambeva guareiensis differs from C. cubataonis by the relative position of the dorsalfin origin that is situated in the vertical through the centrum of 19 th-20th vertebrae (vs. 17 th-18th), the relative position of the pelvic-fin origin that is situated in the vertical through the centrum 17 th vertebrae (vs. 16th), the presence of 11 dorsal-fin rays (vs. 12) and the presence of 10-13 opercular odontodes (vs.14-19). Cambeva cubataonis (Figure $5 \mathrm{~B}$ ) is endemic to the coastal basins of southern Brazil (Figure 4).

Over the last decades, many species have been described for the Paranapanema river drainage (Langeani et al. 2007, Cetra et al. 2016), especially for small size species of Cambeva and Trichomycterus. With several small drainages still not explored, possibly the number of species will continue to rise (Langeani et al. 2007, Cetra et al. 2016), indicating that this drainage that has the greatest known Cambeva diversity to date, may have an even greater diversity than expected.

\section{Key to Paranapanema river drainage species of Cambeva}

1. Presence of pelvic fin girdle.

- Absence of pelvic fin girdle ................................................................................ pascuali

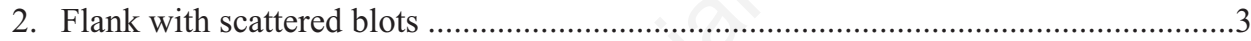

- Flank with three wide dark stripes ............................................................... perkos

3. Caudal-fin hyaline or with blots scattered ...................................................................4

- Caudal-fin with vertical stripe on the edge .................................................. diabola

4. Relative position of the urogenital papillae that is situated in the vertical through the centrum of 23th-24th vertebrae and 9-11 branchiostegal rays ........................ davisi

- Relative position of the urogenital papillae that is situated in the vertical through the centrum of $21 \mathrm{st}-22$ th vertebrae and 8 branchiostegal rays ..................... guareiensis

\section{Acknowledgements}

Thanks are due to H. Rodrigues, P. Hamilton, V.M. Azevedo-Santos for collecting the material. To R. Benine and V.M. Azevedo-Santos for kindly sending the material under their care and taking live photographs of specimens. This study was supported by CAPES (Coordenação de Aperfeiçoamento de Pessoal de Nível Superior - Finance Code 001) and CNPq (Conselho Nacional de Desenvolvimento Científico e Tecnológico - Ministério de Ciência e Tecnologia - Grant number 153329/2015-7).

\section{References}

Arratia G. 1983. Preferencias de habitats de peces siluriformes de aguas continentales de Chile (Fam. Diplomystidae y Trichomycteridae). Studies on Neotropical Fauna and Environment. 18:217237. https://doi.org/10.1080/01650528309360637

Arratia, G. 1990. The South American Trichomycterinae (Teleostei: Siluriformes), a problematic group. In: Peters G, Hutterer R, editors. Vertebrates in the tropics. Bonn: Alexander Koenig Zoological Research Institute and Zoological Museum. Pp. 395-403.

Arratia G, Chang A, Menu-Marque S, Rojas G. 1978. About Bullockia gen. n., Trichomycterus 
mendozensis n. sp. and revision of the family Trichomycteridae (Pisces, Siluriformes). Studies on Neotropical Fauna and Environment. 13:157-194. https://doi.org/10.1080/01650527809360539

Arratia G, Huaquin L. 1995. Morphology of the lateral line system and of the skin of diplomystid and certain primitive loricarioid catfishes and systematic and ecological considerations. Bonner zoologische Monographien. 36:1-110.

Barbosa MA, Costa WJEM. 2003. Trichomycterus potschi (Siluriformes: Loricarioidei): a new trichomycterid catfish from coastal streams of southeastern Brazil. Ichthyological Exploration of Freshwaters. 14:281-287.

Baskin JN. 1973. Structure and relationships of the Trichomycteridae. Supplementary material of de Pinna (2016). Neotropical Ichthyology. 14:S1-S62.

Bizerril CRSF. 1994. Descrição de uma nova espécie de Trichomycterus (Siluroidei, Trichomycteridae) do Estado de Santa Catarina, com uma sinopse da composição da família Trichomycteridae no leste Brasileiro. Arquivos de Biologia e Tecnologia. 37:617-628.

Bockmann FA, Casatti L, de Pinna MCC. 2004. A new species of trichomycterid catfish from the Rio Paranapanema basin, southeastern Brazil (Teleostei: Siluriformes), with comments on the phylogeny of the family. Ichthyological Exploration of Freshwaters. 15:225-242.

Cetra M, Mattox GMT, Ferreira FC, Guinato RB, Silva FV, Pedrosa M. 2016. Headwater stream fish fauna from the Upper Paranapanema River basin. Biota Neotropica. 16:1-6.

Costa WJEM, Bockmann FA. 1993. Un nouveau genre néotropical de la famille des Trichomycteridae (Siluriformes: Loricarioidei). Revue Française d'Aquariologie. 20:43-46.

Datovo A, Bockmann FA. 2010. Dorsolateral head muscles of the catfish families Nematogenyidae and Trichomycteridae (Siluriformes: Loricarioidei): comparative anatomy and phylogenetic analysis. Neotropical Ichthyology. 8:193-246. https://doi.org/10.1590/S1679-62252010000200001

Datovo A, Carvalho M, Ferrer J. 2012. A new species of the catfish genus Trichomycterus from the La Plata River basin, southern Brazil, with comments on its putative phylogenetic position (Siluriformes: Trichomycteridae). Zootaxa. 3327:33-44.

de Pinna MCC. 1989. A new sarcoglandine catfish, phylogeny of its subfamily, and an appraisal of the phyletic status of the Trichomycterinae (Teleostei, Trichomycteridae). American Museum Novitates. 2950:1-39.

Eigenmann CH. 1917. Description of sixteen new species of Pygidiidae. Proceedings of the American Philosophical Society. 56:690-703.

Eigenmann CH. 1918. The Pygidiidae, a subfamily of South American catfishes. Memoirs of the Carnegie Museum. 7:259-398.

Ferrer J, Malabarba LR. 2013. Taxonomic review of the genus Trichomycterus Valenciennes (Siluriformes: Trichomycteridae) from the laguna dos Patos system, southern Brazil. Neotropical Ichthyology. 11:217-246.

Fricke R, Eschmeyer WN, van der Laan R., editors. 2019. Eschmeyer's Catalog of fishes: genera, species, references. http://researcharchive.calacademy.org/research/ichthyology/catalog/ fishcatmain.asp [Accessed 20 February 2019].

Haseman JD. 1911. Some new species of fishes from the rio Iguassú. Annals of the Carnegie Museum. 7:374-387.

Katz AM, Barbosa MA. 2014. Re-description of Trichomycterus cubataonis Bizerril, 1994 (Siluriformes: Trichomycteridae) from the Cubatão river basin, southern Brazil. Vertebrate Zoologie. 64:3-8.

Katz AM, Barbosa MA, Mattos JLO, Costa WJEM. 2018. Multigene analysis of the catfish genus Trichomycterus and description of a new South American Trichomycterine genus (Siluriformes, Trichomycteridae). Zoosystematics and Evolution. 94(2):557-566. https://doi.org/10.3897/zse. 94.29872

Langeani F, Castro RMC, Oyakawa OT, Shibatta OA, Pavanelli CS, Casatti L. 2007. Diversidade da ictiofauna do Alto Rio Paraná: composição atual e perspectivas futuras. Biota Neotropica. 7:181-197.

Miranda Ribeiro P. 1968. Apontamentos ictiológicos. Boletim do Museu Nacional, nova série, Zoologia. 263:1-14.

Nascimento RHC, Frantine-Silva W, Souza-Shibatta L, Sofia SH, Ferrer J, Shibatta OA. 2017. 
Intrapopulational variation in color pattern of Trichomycterus davisi (Haseman, 1911) (Siluriformes: Trichomycteridae) corroborated by morphometrics and molecular analysis. Zootaxa. 4290:503-518. http://dx.doi.org/10.11646/zootaxa.4290.3.5

Nelson JS, Grande T, Wilson MVH. 2016. Fishes of the world. 5th ed. Hoboken: John Wiley and Sons Inc.; I-XLII + 707 p. https://doi.org/10.1002/9781119174844

Ochoa LE, Roxo FF, Do Nascimiento C, Sabaj MH, Datovo A, Alfaro M, Oliveira C. 2017. Multilocus analysis of the catfish family Trichomycteridae (Teleostei: Ostariophysi: Siluriformes) supporting a monophyletic Trichomycterinae. Molecular Phylogenetics and Evolution. 115:7181. https://doi.org/10.1016/j.ympev.2017.07.007

Ochoa LE, Silva GSC, Costa e Silva GJ, Oliveira C, Datovo A. 2017. New species of Trichomycterus (Siluriformes: Trichomycteridae) lacking pelvic fins from Paranapanema basin, southeastern Brazil. Zootaxa. 4319:550-560.

Taylor WR, Van Dyke OC. 1985. Revised procedures for staining and clearing small fishes and others vertebrates for bone and cartilage study. Cybium. 9:107-109. https://doi.org/10.1111/j.10963642.1944.tb00219.x

Valenciennes A. 1832. Nouvelles observations sur le Capitan de Bogota, Eremophilus mutisii. In: Humboldt A, Bonpland A, editors. Recueil d'observations de Zoologie et d'Anatomie Comparée, faites dans l'Ocean Atlantique, dans l'interieur du Nouveau Continent et dans la Mer du Sud pendant les annés 1799, 1800, 1801, 1802 et 1803, deuxième volume. Observations de Zoologie et d'Anatomie comparée. Pp. 341-348.

This article is distributed under the terms of the Creative Commons Attribution 